\title{
STRATEGI BELAJAR BERBASIS ANEKA SUMBER
}

\author{
Rosa Meriyana A.
}

\begin{abstract}
The advancement of information and communication technoloy has significant impacts into all aspects of human life including in education. The teachers and the text books are not the only learning resources for the student any more. As there are abundant informations available for students to meet their learning needs. The informations are presented in various media and easy to access. Teaching and learning process at the education institutions should be adjusted to the availability oflearning resources. This article discussess Resource Based Learning (RBL) by clarifying the concept, describing how to implement of RBL and showing the example of RBL implementation in Indonesia. It concludes that RBL can solve a number of learning problems particularly in long life education. Therefore, as early as possible everybody should learn how to learn by using RBS.
\end{abstract}

Kata kunci: belajar berbasis aneka sumber, open learning, distance learning, flexible learning, learning resources, resources based, belajar sepanjang hayat.

\section{PENDAHULUAN}

\section{Belajar}

Pada dasarnya belajar dilakukan bukan hanya untuk memenuhi kebutuhan fisik, tetapi melainkan kebutuhan non-fisik, yaitu rasa ingin tahu dan merupakan prasyarat untuk mencapai kemampuan yang lebih tinggi, sehingga diharapkan dengan semua itu manusia bisa memecahkan berbagai masalah. Tidak dapat dipungkiri, kehidupan manusia penuh dengan kebutuhan baik yang bertujuan untuk meningkatkan kualitas hidup ataupun sekedar bertahan hidup, dengan demikian diperlukan berbagai kompetensi

Menurut Gagne (1984) belajar didefinisikan sebagai suatu proses dimana suatu organisme berubah perilakunya akibat suatu pengalaman. Sementara itu, Galloway dalam Soekamto (1992: 27) mengatakan belajar merupakan suatu proses internal yang mencakup ingatan, retensi, pengolahan informasi, emosi dan faktor-faktor lain berdasarkan pengalamanpengalaman sebelumnya. Sedangkan Morgan mengatakan bahwa suatu kegiatan yang dikatakan belajar memiliki tiga ciri sebagai berikut: (a) belajar merupakan perubahan tingkah laku; (b) perubahan terjadi karena latihan dan pengalaman, bukan karena pertumbuhan; (c) perubahan tersebut harus bersifat permanen dan tetap ada untuk waktu yang cukup lama. (http://www.ut.ac.id).

Menurut teori behaviorisme belajar adalah perubahan tingkah laku. Belajar adalah pembuka dari tidak tahu menjadi tahu dari tidak paham menjadi paham, dari kurang terampil menjadi mahir dengan kata lain terjadi perubahan mental dalam diri seseorang. (Abd. Aziz Ahmad \& Etin Solihatin, 2003, 152).

Dengan demikian dapat disimpulkan bahwa belajar merupakan suatu proses internal yang mencakup ingatan, retensi, pengolahan informasi, emosi dan faktor-faktor lain berdasarkan pengalaman, bukan pertumbuhan, sehingga terjadi perubahan mental dalam diri seseorang yang bersifat permanen dan tetap ada untuk waktu yang cukup lama.

\section{Mengapa Belajar Berbasis Aneka Sumber}

Kebutuhan akan belajar dalam rangka meningkatkan kualitas hidup dan bertahan hidup mendorong seseorang untuk belajar, dari mana saja, kapan saja dan dengan cara apapun. Kenyataannya, belajar di lingkungan formal dan nonformal telah dirasakan oleh masyarakat pada umumnya sebagai suatu yang semakin sulit dijangkau sementara di sisi lain masyarakat kian menyadari arti penting belajar, dengan demikian kebutuhan akan belajar dirasakan semakin meningkat. Namun, hanya sebagian kecil masyarakat yang dapat dengan mudah menikmati proses pembelajaran yang bermutu tinggi di institusi unggulan, sementara itu jauh lebih banyak masyarakat yang tidak mampu memperoleh pendidikan anggota keluarganya. Di sisi lain, kebutuhan belajar tersebut tetap harus dipenuhi bukan hanya untuk meningkatkan kualitas hidup ataupun sekedar bertahan hidup, tetapi bahkan berusaha memenangkan persaingan di tengah arus global.

Saat ini, implikasi tatanan sosial, kemajuan teknologi dan ilmu pengetahuan memudahkan manusia memperoleh informasi tentang ilmu pengetahuan dari beraneka sumber. Dalam istilah pendidikan kita mengenal BEBAS (belajar berbasis 
aneka sumber). BEBAS merupakan proses belajar alternatif bagi peserta didik, dengan BEBAS seorang anak didik dapat belajar dengan bantuan sumber belajar apa saja, belajar dari siapa saja, belajar kepada siapa saja, belajar tentang apa saja, dan belajar untuk tujuan apa saja sehingga manusia (masyarakat) dituntut untuk berubah dalam berbagai hal, diantaranya pengembangan kompetensi kognitif tingkat tinggi (quality thinking skill) dan interpersonal skill.

Tuntutan pembangunan masyarakat seperti ini hanya dapat dipenuhi dengan pembinaan dan pengembanganan manusianya, yang diharapkan akan mampu mandiri, dan mampu berintegrasi terhadap berbagai perubahan yang begitu cepat dalam masyarakat.untuk dapat mengembangkan sumber daya manusia (SDM) tidak ada cara yang paling tepat selain belajar, belajar, dan belajar.

Untuk itu diperlukan sarana belajar berbasis aneka sumber. apa dan bagaimana belajar berbasis aneka sumber akan diuraikan dalam makalah, yang pengertian, manfaat, dan implementasi Belajar Berbasis Aneka Sumber.

\section{Pengertian Belajar Berbasis Aneka Sumber}

BEBAS dalam Bahasa Inggris disebut dengan Resource-Based Learning (RBL) yang diartikan sebagai pencapaian tujuan akan materi dan informasi melalui dengan berbagai sumber. Dalam RBL siswa menjadi pebelajar aktif, sementara guru dan pustakawan hanya menjadi motivator dan fasilitator. Pada dasarnya terdapat dua karakteristik khusus dari RBL, yaitu pada fleksibilitas dan kemudahan dalam penyesuaian dalam berbagai gaya belajar dan materi pelajaran, dan juga pada otonomi siswa dalam belajar. (http://www.library.queensu.ca)

RBL disebut sebagai payung dari beberapa pengertian seperti open learning, flexible learning, individualized learning, computer aided learning, dan project based learning. (http://olkg.cranfield.ac.uk). Sedangkan menurut Dorrel (dalam Abd. Aziz Ahmad dan Etin Solihatin, 2003, 154), BEBAS sangat terkait dengan beberapa pengertian dan sistem pembelajaran diantaranya open learning, distance learning, flexible learning, learning resources, dan resources based. Di bawah ini merupakan penjelasan dari istilah-istilah yang terkait dengan BEBAS menurut Dorrel:

1. Open learning (pendidikan terbuka) adalah prinsip belajar "terbuka" bagi semua orang. Tidak ada prakualifikasi, seperti batas usia, status sosialekonomi, atau harus lulus level tertentu. Pebelajar dapat memilih dimana, kapan, bagaimana mereka akan belajar, menentukan tindakan belajar, serta bebas dari segala interupsi

2. Distance learning (http://Edlponline).

a. Menurut The California Distance Learning Project (CDLP) pendidikan jarak jauh adalah sistem penyampaian pembelajaran yang menghubungkan pebelajar dengan sumber pendidikan.

b. Menurut AT dan T, pendidikan jarak jauh adalah sistem atau proses langsung yang menghubungkan pebelajar dengan sumber yang jauh.

c. Menurut The United State Learning Assosiation (USDLA), pendidikan jarak jauh adalah pengantaraan pendidikan atau pelatihan melalui pembelajaran dengan media elektronik. Pendidikan jarak jauh mengacu kepada situasi belajar mengajar dimana instruktur dan pebelajar berada dalam jarak yang terpisah secara geografis, karena itu mengandalkan peralatan elektronik dan bahan cetakan untuk mengantar pembelajaran.

3. Flexible learning (belajar fleksibel) adalah jenis belajar yang dapat menggunakan berbagai sumber belajar dalam semua bentuk, dan dapat dipakai untuk segala pola yang menggunakan sumber belajar.

4. Learning resource (sumber belajar) adalah material pembelajaran (learning material), termasuk; Video, buku, kaset audio, Computer-based Training, dan paket pembelajaran yang mengkombinasikan lebih dari satu sumber belajar.

5. Resource-based adalah belajar berbasis aneka sumber (BEBAS), secara luas meliputi jenis sistem pendidikan, seperti pendidikan terbuka, pendidikan jarak jauh, belajar fleksibel, yang menggunakan aneka sumber.

Pada prinsipnya ada tiga hal pokok proses perencanaan kegiatan pembelajaran, yaitu; pertama, bagaimana pebelajar melakukan kegiatan belajar. belajar berbasis aneka sumber memungkinkan setiap pebelajar melakukan kegiatan belajar sesuai dengan gaya belajar yang dimilikinya. Pebelajar dapat mendengarkan rekaman audio (tape recorder) dalam belajar bahasa asing; kedua, kesempatan belajar, seorang pebelajar dapat mengatur kapan waktu yang cocok untuk mereka belajar, apakah pagi, sore atau malam, karena kesempatan belajar bersifat individual; ketiga, kemauan dan motivasi untuk belajar, para ahli 
membedakan motivasi atas dua hal, yaitu dorongan dari dalam (instrinsik) dan dari luar (ekstrinsik), karena tanpa motivasi yang tinggi proses belajar akan sulit terlaksana dengan baik.

\section{Manfaat belajar Berbasis Aneka Sumber Bagi Pebelajar}

Praksis pendidikan memandang pendidikan tidak hanya terbatas di sekolah saja, akan tetapi juga berlaku di luar sekolah sehingga menjangkau anakanak yang termasuk kelompok marginal (anak pedesaan, daerah terpencil bahkan gelandangan). Sebagian kecil masyarakat dengan relatif mudah mendapatkan atau menikmati proses pembelajaran yang bermutu tinggi di institusi unggulan sementara jauh lebih banyak mereka yang tidak mampu memperoleh pendidikan (menyekolahkan) anggota keluarganya di institusi yang lumayan baik saja.

Mahalnya biaya pendidikan (belajar) mendorong alternatif pemecahannya, salah satunya dengan BEBAS karena seorang anak didik dapat dapat belajar dengan bantuan sumber belajar apa saja, belajar dari siapa saja, belajar kepada siapa saja, belajar tentang apa saja dan belajar untuk tujuan apa saja. Belajar dengan, menunjukkan bahwa dalam proses belajar tersebut didampingi, dengan perantaraan, menggunakan sesuatu yang mendukung terjadinya proses belajar itu untuk mencapai tujuan belajar. Dalam BEBAS, hal ini ditafsirkan dengan penggunaan aneka sumber belajar baik insani maupun non-insani. Misalnya untuk belajar desain grafis pembelajar menggunakan perantaraan komputer. Belajar dari, menunjukkan bahwa dalam proses belajar terdapat sesuatu yang di gali sehingga pebelajar menguasai dan mencapai tujuan belajar, kaitannya dengan BEBAS adalah segala sesuatu dapat menjadi inspirasi terjadinya belajar, sehingga hal tersebut dapat disebut sebagai sumber belajar. Misalnya peristiwa hujan dapat kita jadikan sumber belajar. Belajar kepada, hal ini menunjukkan adanya objek yang dijadikan nara sumber. Misalnya belajar kepada Ustadz, Kyai, Pamong Belajar, Tutor, Guru dan lain-lain. Belajar tentang menunjukkan adanya spesifikasi materi yang dikuasai sehingga proses belajar menjadi terfokus kepada satu atau berbagai hal yang sejenis. Misalnya belajar matematika. Belajar untuk, hal ini dapat menunjukkan adanya tujuan akhir belajar. Kata untuk disini bisa juga dipadankan dengan demi, guna. Misalnya belajar menjadi sopir yang baik, maka seseorang harus belajar tentang mobil, jalan raya, aturan lalu lintas dan juga ia harus belajar dari/ kepada sopir lainnya. (Mohammad Tahmid, 2006, http:/ / www.pustekkom. go.id).

Abdul Aziz Ahmad dan Etin Solihatin berpendapat bahwa manfaaat Belajar Berbasis Aneka Sumber adalah sebagai berikut; Pertama yang terpenting adalah menemukan bakat yang terpendam yang selama ini tidak nampak. Pengembangan keinginan untuk mengembangkan diri setelah tamat pendidikan formal adalah bentuk pendidikan sepanjang hayat, dengan demikian akan diperoleh kemampuan baru sesuai dengan harapan dan perkembangan terakhir. Kedua, menggunakan sumbersumber yang memungkinkan pembelajaran berlangsung sepanjang tahun dan dapat menyeimbangkan antara keterampilan dan pengetahuan. Ketiga, seseorang dapat belajar sesuai kondisinya, pada waktu belajar dan waktu kerja, tanpa rasa cemas dalam persaingan.

Dari beberapa ahli juga mengemukakan bahwa BEBAS memberikan berbagai keuntungan, diantaranya (Elisna, 2003, 168):

1. Selama pengumpulan informasi terjadi kegiatan berfikir, yang pada gilirannya akan menimbulkan pemahaman yang mendalam dalam belajar (Mac Farlerne,1992).

2. Meningkatkan pembentukan keterampilan berpikir seperti keterampilan memecahkan masalah, memberikan pertimbangan-pertimbangan dan melakukan evaluasi melalui penggunaan informasi dan penelitian secara mandiri (Reisnick, 1987; Todd \& Inc Nicholas, 1994/1995).

3. Mendorong terjadinya pemusatan perhatian terhadap topik sehingga membuat peserta didik menggali lebih banyak lagi informasi dan menghasilkan produk belajar yang lebih bermutu (Kulthan, 1993).

4. Meningkatkan perolehan keterampilan memproses informasi secara efektif dengan mengetahui sifat dasar informasi dan keberagamannya (Cleaver, 1986).

5. Meningkatkan sikap murid dan guru terhadap materi pembelajaran dan prestasi akademik (Cull, 1991).

6. Membuat orang antusias belajar dan terinspirasi untuk berpartisipasi aktif (Willbert, 1976).

7. Meningkatkan prestasia kademik dalam penguasaan materi, sikap dan berpikir kritis (Barrilant, 1965).

Berkenaan dengan keuntungan belajar berbasis aneka sumber yang melekat dengan belajar bagaimana belajar, Munford sebagaimana yang dikutip oleh Dorrel (1993) mengemukakan bahwa belajar berbasis aneka 
sumber dapat: meningkatkan kemampuan belajar, meningkatkan motivasi belajar, menumbuhkan kesempatan belajar yang baru, mengurangi ketergantungan pada guru dan menumbuhkan rasa percaya diri dalam menghadapi tantangan baru.

\section{Implementasi Belajar Berbasis Aneka Sumber}

Implikasi perkembangan teknologi sebagai daya yang memasuki berbagai bidang kehidupan, termasuk bidang pendidikan. Bagaimana teknologi dapat berperan dalam pendidikan sehingga memberikan peluang bagi para pebelajar untuk memanfaatkannya sebagai sumber belajar perlu memperhatikan beberapa hal yaitu (Abdul Aziz Ahmad dan Etin Solihatin, 2003, 159):

1. Proses pendidikan berpusat pada siswa/ mahasiswa.

Pendidik dengan visi atau sikap demokratis dalam praksis mengajarnya tak dapat menghindar dari tuntutan pelajar akan pengakuan atas kemampuan, keingintahuan, dan otonomi siwa itu sendiri, pendidik harus memastikan bahwa mengajar bukan hanya menyediakan muatannya tetapi mengajak siswa/mahasiswa untuk berpikir dengan tepat dan tidak menuruti kehendak hafalan mekanis atau pengulangan irama ritmis dari partitur dan ide-ide dengan mengorbankan tantangan kreatif (Paulo Freire 1998).

Siswa pada dasarnya memiliki dua segi mental, yang satu berasal dari kepala (head) yang cirinya kognitif seperti IQ, dan yang lainnya berasal dari sanubari (heart) yaitu dimensi emosional (segi afektif), sehingga dalam pendekatan mendidik, berdasarkan visi atau sikap demokratis dalam mengajarnya pendidik harus mamapu bertugas sebagai pembimbing dalam melatih, memotivasi memfasilitasi agar siswa/mahasiswa dapat berperan aktif dalam proses pembelajaran.

2. Peranan institusi pendidikan "elektronik"

Dalam pembelajaran orang dewasa telah terjadi perubahan yang cepat khususnya dalam pengembangan metode pengajaran termasuk didalamnya pemanfaatan teknologi jaringan komputer kecepatan tinggi. Inti pokok pelayanan pendidikan elektronik adalah infrastruktur jaringan multi media internal yang membolehkan institusi lain untuk mengakses, menciptakan , dan memberi pelayanan multimedia pendidikan dalam aneka macam format dan aneka cara. Di sisi lain, peranan institusi program elektronik sebagai berikut.

a. Memberi informasi tentang kebutuhan dan peluang pendidikan dan pelatihan b. Memberi pengawasan kualitas

c. Memberi akreditasi melalui penilaian belajar yang Independent

d. Mengembangkan kurikulum yang koheren dan tepat

e. Menjadi broker dan mensahkan kursus-kursus, bahan-bahan pendidikan dan pelatihan dari pemasok

f. Memberi pelayanan penggunaan dan komunikasi bahan-bahan pembelajaran

g. Menyediakan program multimedia yang user friendly baik impor maupun ekspor

h. Membuat jaringan antar pebelajar dan antar infrastruktur

i. Menciptakan bahan-bahan multimedia pendidikan berkualitas tinggi dalam bentuk yang mudah diperoleh

j. Mengadakan penelitian untuk kebutuhan pendidik dan pelatihan

k. Menggunakan teknologi-teknologi baru untuk pengembangan pendidikan dan pelatihan serta mengevaluasi penggunaannya

Konfigurasi teknis sebuah institusi pendidikan elektronik memiliki fungsi produksi, broker, dan manajemen berbagai input yang berupa audio, program, maupun video. Sedangkan outputnya dapat berupa audio, program, barang cetakan, komunikasi dengan radio seluler, satelit, atau server multimedia.

3. Prinsip pedagogi dan Disain Penilaian antar budaya

Sumber pembelajaran untuk siswa merupakan perhatian utama di seluruh dunia karena berada dalam arena pendidikan tanpa batas yang dapat dipenuhi melalui World wide web. World wide web bila dimanfaatkan sebagai sumber belajar perlu memperhatikan prinsip pedagogi. Tujuan pembelajaran on-line adalah menjamin bahwa pedagogi dan kurikulum fleksibel , dapat menyesuaikan diri dan relevan bagi siswa dari latar belakang, sehingga aspek pedagogi bersifat mendukung antar budaya.

Hal penting yang perlu dipertimbangkan dalam pendidikan on-line adalah kurikulum. Mengkonseptualisasikan kurikulum inklusif merupakan langkah pertama ke arah perencanangan aktivitas pembelajaran on-line yang tepat. Kurikulum inklusif bertujuan untuk meningkatkan timbal balik, arus ide dua arah, dan nilai-nilai antara. Kurikulum ini mempunyai ciri-ciri:

a. Menilai budaya, latar belakang dan pengalaman mahasiswa; 
b. Inklusif gender, budaya atas perbedaan yang berhubungan dengan etnik, bahasa dan latar belakang sosio ekonomi;

c. Mengakui bahwa setiap keputusan kurikulum adalah pemilihan dari pada kebenaran lengkap;

d. Menjadikan eksplisit pola mata pelajaran pendukung yang rasional;

e. Responsif terhadap dasar pengetahuan dasar siswa.

Komponen-komponen dasar kurikulum inklusif sebagai suatu hubungan timbal balik antara penilaian, pengajaran, aktivitas pembelajaran, dan hasil-hasil pembelajaran. Hal ini berarti bahwa semua dimensi harus dipertimbangkan dan saling terkait dalam mengajar dan merancang lingkungan web.

\section{Contoh Aplikasi BEBAS di Indonesia}

1. Aku Cinta Indonesia: Serial Televisi Pendidikan Pertama

Di Indonesia, pada dasarnya telah dicanmtukan dalam sebuah kebijakan mengenai pemanfaatan siaran radio dan televisi sebagai sarana dalam upaya pemerataan pendidikan. Namun pada kenyataannya hingga dua akhir PELITA hal tersebut masih merupakan wacana. Sementara itu, Malaysia telah menggunakan siaran radio dan televisi untuk sekolah sejak tahun 1972. Televisi siaran sekolah sudah mengudara selama enam jam sehari termasuk siaran ulang. Sementara itu di Indonesia, untuk pertama kalinya atas bantuan dari UNICEF, akhirnya dibuatlah prototipe program pendidikan untuk anak-anak dengan menggabungkan unsur edukaitf dan hiburan. Program ini, yang pembuatannya dikerjakan oleh Pustekkom dan lembaga-lembaga pendukung lain, kemudian dinamakan ACI, yaitu merupakan akronim dari Aku Cinta Indonesia sekaligus akromim dari insial pemerannya, yaitu Amir, Cici dan Ito. Program siaran televise pendidikan tersebut pada dasarnya meliputi aspekaspek kerja sama, kegigihan, kesetiakawanan, sportivitas, kejujuran, dan sebagainya. (Miarso, 2004, 365)

2. E-Learning

Kecenderungan untuk mengembangkan $e$ learning sebagai salah satu alternatif pembelajaran di berbagai lembaga pendidikan dan pelatihan semakin meningkat sejalan dengan perkembangan di bidang teknologi komunikasi dan informasi. Infrastuktur di bidang telekomunikasi yang menunjang penyelenggaraan e-learning tidak lagi hanya memonopoli kota-kota besar, tetapi secara bertahap sudah mulai dinikmati oleh mereka yang berada di kota-kota tingkat kabupaten. E-learning di Indonesia masih sangat tertinggal jika dibandingkan dengan negara-negara lain, sebut saja perguruan tinggi di Kanada telah menjadikan pembelajaran elektronik sebagai salah satu alternatif pembelajaran yang dapat dipilih oleh mahasiswa. namun saat ini pemanfaatan e-learning sudah banyak diterapkan dibeberapa perguruan tinggi di Indonesia. Perguruan tinggi yang telah melaksanakan e-learning di Indonesia antara lain:

a. Universitas Terbuka (UT) telah melaksanakan uji coba penyelenggaraan Tutorial Elektronik (Tutel) pada tahun 1999 bagi para mahasiswanya. Alasan dilakukannya uji coba tutorial elektronik ini adalah sesuai dengan mahasiswa untuk membantu mereka memecahkan kesulitan yang dihadapi selama belajar mandiri (Anggoro, 2001 dalam Sudirman Siahaan, http://www.depdiknas. go.id)

b. Universitas Gajah Mada (UGM) telah memulai mempersiapkan kegiatan pembelajaran yang memanfaatan internet untuk program pascasarjana di bidang pengelolaan umum rumah sakit dan pengelolaan layanan kesehatan pada tahun 1996 (Prabandari dkk., 1998 dalam Sudirman Siahaan, http:// www.depdiknas.go.id)

\section{SLTP Terbuka}

Pada PELITA II pemerintah telah menetapkan dalam pembangunan pendidikan yang salah satunya adalah memperluas kesempatan belajar bagi anak-anak usia 7-12 tahun. Tindak lanjut dari kebijakan tersebut yaitu pada tahun 1974 keluarlah Inpres Nomor 10, yang salah satu diantaranya adalah pembangunan gedunggedung SD Inpres secara besar-besaran. Namun hal ini menimbulkan permasalahan baru, yaitu lulusan-lulusan SD-SD yang sudah ada ditambah lulusan-lulusan dari SD Inpres tidak dapat ditampung oleh SLTP. Pada tahun 1977, melalui Rapat Kerja Nasional yang dihadiri kalangan pendidik sektor pemerintah maupun swasta diputuskan bahwa: (1) mengoptimalkan SMP yang ada; (2) penambahan jumlah SMP denga membangun SMP baru; (3) membuka kursuskursus keterampilan; (4) membuka subsistem pendidikan tingkat SMP yang disebut SMP Terbuka. Pertama kali SMP Terbuka dirintis di lima lokasi yaitu, Kalianda-Lampung Selatan, Plumbon-Jawa 
Barat, Adiwerna-Jawa Tengah, Kalisat-Jawa Timur, dan Terara-NTB. Sejak dicanangkannya program Wajib Belajar Pendidikan Dasar 9 (Sembilan) tahun pada tahun 1994, SMP Terbuka dianggap sebagai salahs atu pola yang dapat menopang keberhasilan program tersebut. Sejak tahu 2000 lokasi SLTP Terbuka didata dan diverifikasi ulang dan diperoleh data jumlah SLTP Terbuka yang masih beroperasi sebanyak 2.870 lokasi dengan jumlah siswa sebanyak 232.395 orang. Data ini diperoleh dari laporan yang masuk dari masing-masing Kabupaten/ Kota yang ditopang oleh laporan dari masing-masing sekolah. (Nurdin Ibrahim, 2004, 281).

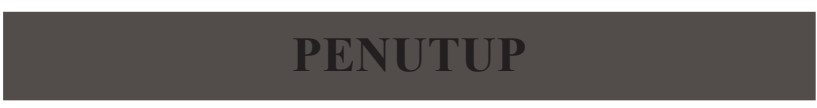

Kebutuhan manusia yang semakin meningkat semakin membuka mata masyarakat kita untuk terus belajar, belajar dan belajar. Konsep belajar sepanjang hayat, pada sebagian masyarakat telah tertanam dengan kuat, hal ini pun dikarenakan masyarakat berusaha semaksimal mungkin untuk meningkatkan kualitas hidupnya, ataupun sekedar bertahan hidup. Namun tak dapat dipungkiri, berbagai macam keterbatasan masih sangat dirasakan oleh sebagian masyarakat terutama yang berkaitan dengan pemenuhan kebutuhan belajar.

Pergeseran dari era industri menjadi era informasi menuntut terjadinya perubahan dalam berbagai bidang, begitu juga dalam bidang pendidikan. Di era informasi ini, semua warga belajar mulai dari anak pra-sekolah sampai mahasiswa perguruan tinggi, setiap saat dihadapkan pada berbagai informasi dalam jumlah yang sangat banyak. Informasi tersebut disebarkan melalui berbagai media, baik cetak maupun elektronik, dari teknologi sederhana sampai yang canggih, seperti CD Rom, Internet, dll. Ketersediaan beraneka macam sumber belajar baik melalui media elektronik, cetak dan fenomena alam dapat membuka peluang yang besar untuk menentukan sikap dalam hal menerima, menolak, memfilter informasi yang ada. Oleh karena itulah, keterbatasan yang dimiliki warga belajar dalam memenuhi kebutuhan belajarnya dapat teratasi dengan Belajar Berbasis Aneka Sumber.

BEBAS sangat terkait dengan beberapa pengertian dan sistem pembelajaran diantaranya open learning, distance learning, flexible learning, learning resources, dan resources based. Adapun manfaat dari BEBAS yaitu terutama terletak pada fleksibilitas dan kemudahan dalam penyesuaian dalam berbagai gaya belajar dan materi pelajaran, dan juga pada otonomi siswa dalam belajar. Oleh karena itulah BEBAS menjadi salah satu alternatif yang cukup banyak dimanfaatkan oleh warga belajar yang kesulitan memenuhi kebutuhan belajarnya melalui pendidikan formal maupun nonformal.

Dengan pergerseran ini pada dasarnya teknologi dapat berperan dalam pendidikan sehingga memberikan peluang bagi para pebelajar untuk memanfaatkannya sebagai sumber belajar perlu memperhatikan beberapa hal yaitu proses pendidikan berpusat pada siswa/ mahasiswa; peranan institusi pendidikan "elektronik"; dan prinsip pedagogi dan disain penilaian antar budaya.

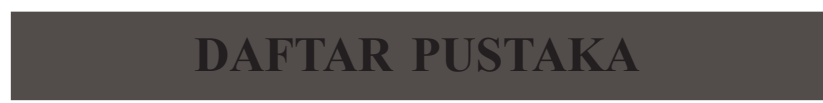

Anon. (2003).Belajar, mengajar dan pembelajaran. Dari http://www.ut.ac.id. Diakses September 2001

Anon. (2006). Resources based-learning. Dari http:// www.library.queensu.ca. diakses tanggal 19 September 2006.

Anon. (2006). Resources based-learning. Dari http:// www.ut.ac.id. diakses 19 September 2006

Anon. Populer: Dekolonisasi metodologi edisi 15. Tahun IV. Jurnal Ilmu Sosial Transformatif, Wacana Pendidikan

Azis, A. \& Solihatin, E. (2003). Upaya peningkatan kualitas dan produktivitas sumber daya manusia. (ed. Dewi Padmo). Jakarta: Universitas Terbuka.

Elisna. (2003). Belajar berbasis aneka sumber: Peluang dan tantangan bagi pendidikan http://www.ut.ac.id

Miarso, Y. (2004). Menyemai benih teknologi pendidikan. Jakarta: Prenada Media.

Prawiradilaga, D. S. \& Siregar, E. (2004). Mozaik teknologi pendidikan. Jakarta: Prenada Media.

Siahaan, S. (2006). E-learning (pembelajaran elektronik) sebagai salah satu alternatif kegiatan pembelajaran. Dari http:// www.depdiknas.go.id/jurnal/42/sudirman.htm. Diakses tanggal 8 November 2006

Tahmid, M. (2006). Belajar berbasis aneka sumber: Peluang dan tantangan. Dari http://www.pustekkom.go.id. Diakses tanggal 19 September 2006.

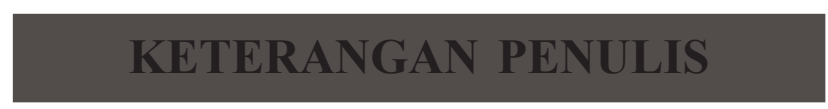

Rosa Meriyana A., S.Pd. adalah mahasiswi S2 Teknologi Pendidikan di Program Pasca Sarjana UNJ, selain itu juga aktif sebagai staf sekretariat dalam dewan redaksi jurnal ilmiah. 